\title{
ANALISIS DEFECT PRODUK VIRO CORE COLLECTION DENGAN METODE FAULT TREE ANALYSIS, ANALISIS FAKTOR DAN PERBANDINGAN
}

\author{
Agus Syahabuddin*, Marjuki Zulziar \\ Program Studi Teknik Industri, Fakultas Teknik, Universitas Pamulang \\ Email: dosen01863@unpam.ac.id; dosen01775@unpam.ac.id
}

Artikel masuk : 28-10-2020

Artikel direvisi : 15-02-2021

Artikel diterima : 29-03-2021

${ }^{*}$ Penulis Korespondensi

\begin{abstract}
Abstrak -- PT. Polymindo Permata adalah perusahaan ekstrusi plastik yang memproduksi rotan sintetis. Salah satu produk fast moving andalannya adalah Viro Core Collection (VCC) yang menyumbang 50\% dari total order. Defect produk VCC masih jauh lebih tinggi dari target 3\%. Tujuan penelitian ini adalah untuk meningkatkan kualitas dan mengurangi waste dengan pendekatan sistematis menggunakan metode Fault Tree Analysis (FTA), analisis faktor dan analisis perbandingan. Hasil diagram Pareto menunjukan penyebab cacat tertinggi adalah warna belang mencapai $23.24 \%$ dari total produk cacat. Hasil analisis FTA dan analisis faktor diketahui faktor penyebab defect warna belang disebabkan karena metode mixing material untuk mesin Co-extruder setiap Setter yang berbeda-beda, ekstrusi material IHMB menggunakan mesin Single Screw Extruder, sistem mesin Co-extruder tidak berfungsi maksimal, dan Heater tidak berfungsi maksimal. Setelah improvement diterapkan kemudian dilakukan analisis perbandingan Independent-Sample T-Test. Hasil penelitian menunjukkan bahwa metode mixing material untuk mesin Co-extruder setiap Setter yang berbeda-beda sebelum ada SOP dibanding setelah ada SOP berbeda signifikan, sehingga faktor ini adalah paling dominan untuk meningkatkan kualitas dan menurunkan defect.
\end{abstract}

Kata kunci: Analisis Faktor; Analisis Perbandingan; Ekstrusi Plastik; Fault Tree Analysis; Waste

\begin{abstract}
PT. Polymindo Permata is a plastic extrusion company that produces synthetic rattan. One of its fast-moving flagship products is the Viro Core Collection (VCC) which accounts for $50 \%$ of total orders. Defects of VCC products are still much higher than the target of 3\%. This research aims to improve quality and reduce waste with a systematic approach using the Fault Tree Analysis (FTA) method, factor analysis, and comparative analysis. The Pareto diagram results show that the highest cause of defects is striped color, reaching $23.24 \%$ of the total defect products. The results of FTA analysis and factor analysis show that the factors causing the striped color defect are due to the different material mixing methods for the Co-extruder machine, the extrusion of IHMB material using a Single Screw Extruder machine, the Co-extruder machine system is not functioning optimally, and the Heater is not functioning optimally. After the improvement was applied, a comparative analysis of the Independent-Sample T-Test was carried out. The results showed that the material mixing method for the Co-extruder machine for each Setter was different before there was an SOP compared to after the SOP was significantly different, so this factor was the most dominant to improve quality, and lowering the defect.
\end{abstract}

Keywords: Factor Analysis; Comparative Analysis; Plastic Extrusion; Fault Tree Analysis; Waste

\section{PENDAHULUAN}

Peningkatan daya saing ekonomi pasca kesepakatan Masyarakat Ekonomi ASEAN (MEA) pada akhir 2015 menciptakan kawasan bebas perdagangan Asia Tenggara. Hal ini, membuat dunia manufaktur Indonesia semakin kompetitif dengan persaingan antar kompetitor yang melibatkan perusahaan dalam negeri melainkan kompetitor di kawasan ASEAN (Dewi \& Sartono, 2014). Perusahaan dituntut menjaga kualitas produk dengan menjaga stabilitas output yang sesuai spesifikasi dan harga yang tetap bersaing. 
Tentu spesifikasi mutu yang ditetapkan mampu menjawab harapan pasar (Alfatiyah et al., 2020; Hazmi \& Karningsih, 2012). Berkaitan dengan hal tersebut maka kepuasan pelanggan (customer satisfaction) akan terpenuhi (Fajarusman et al., 2017; Pusporini \& Andesta, 2012).

PT. Polymindo Permata adalah perusahaan ekstrusi plastik yang memproduksi rotan sintetis dengan merek Viro. PT. Polymindo Permata terletak di Jl. Industri 2 Blok F No. 8, Kawasan Industri Jatake, Tangerang. Viro merupakan produk rotan sintesis bermotif sebagai bahan baku pembuatan beberapa produk jadi seperti building partition, surface wall, furniture, handicraft atau produk lainnya. Salah satu varian Viro yang Fast Moving adalah Viro Core Collection (VCC) dengan volume order varian produk Viro Core Collection (VCC) sebesar $50 \%$ dari total order.

Permasalahan yang dihadapi adalah rendahnya produktivitas dan tingginya defect pada varian produk Viro Core Collection (VCC) yaitu sebesar $33,78 \%$. Total persentase waste produk VCC masih jauh dari harapan perusahaan sebesar 3\%. Maka dari fenomena tersebut, perlu dilakukan analisis untuk meningkatkan produktivitas (Cahyanti et al., 2013; Pusporini \& Andesta, 2012) dan menurunkan waste (Herudi et al., 2020; Prakoso et al., 2017). Metode Fault Tree Analysis (FTA) ini mampu menemukan akar masalah yang paling mungkin menyebabkan waste varian produk VCC. Metode Analisis faktor merupakan pendekatan statistik untuk menganalisis hubungan diantara beberapa variabel dan menjelaskan variabel-variabel dalam keadaan berdasarkan dimensi, kemudian pengujian Analisis Perbandingan Independent-Sample T Test untuk mencari apakah ada perbedaan secara signifikan setelah perbaikan berdasarkan faktor-faktor yang teridentifikasi

Tujuan penelitian ini adalah mengetahui tingkat kecacatan produk vcc di PT. Polymindo permata, dan mengetahui mengetahui faktorfaktor yang terbentuk terkait kecacatan produk Viro Core Collection (VCC) menggunakan metode FTA dan Analisa Faktor serta mengetahui status signifikan dengan uji Perbandingan IndependentSample $T$ Test terkait improvement yang diusulkan terhadap penurunan defect produk VCC.

\section{METODE PENELITIAN}

Jenis penelitian yang digunakan adalah kombinasi penelitian kuantitatif dan penelitian kualitatif. Teknik penggabungan dilakukan untuk mengembangkan fenomena dan hubunganhubungannya serta menggunakan model-model untuk lebih menekankan pada aspek pemahaman terhadap suatu masalah (Jakfar et al., 2014).

Data yang diambil dalam penelitian ini adalah jumlah produksi dan defect periode Januari-Desember 2019, teknik pengambilan datanya adalah dengan observasi lapangan dan penyebaran kuesioner

Pendekatan yang dilakukan dengan menggunakan metode Fault Tree Analysis (FTA), Analisis Faktor dan Analisis Perbandingan Independent-Sample T Test (Gambar 1). Metode Fault Tree Analysis (FTA) digunakan untuk mendeteksi adanya gejala agar dapat mengetahui akar penyebab suatu masalah yang dimulai dari kejadian puncak (Top).

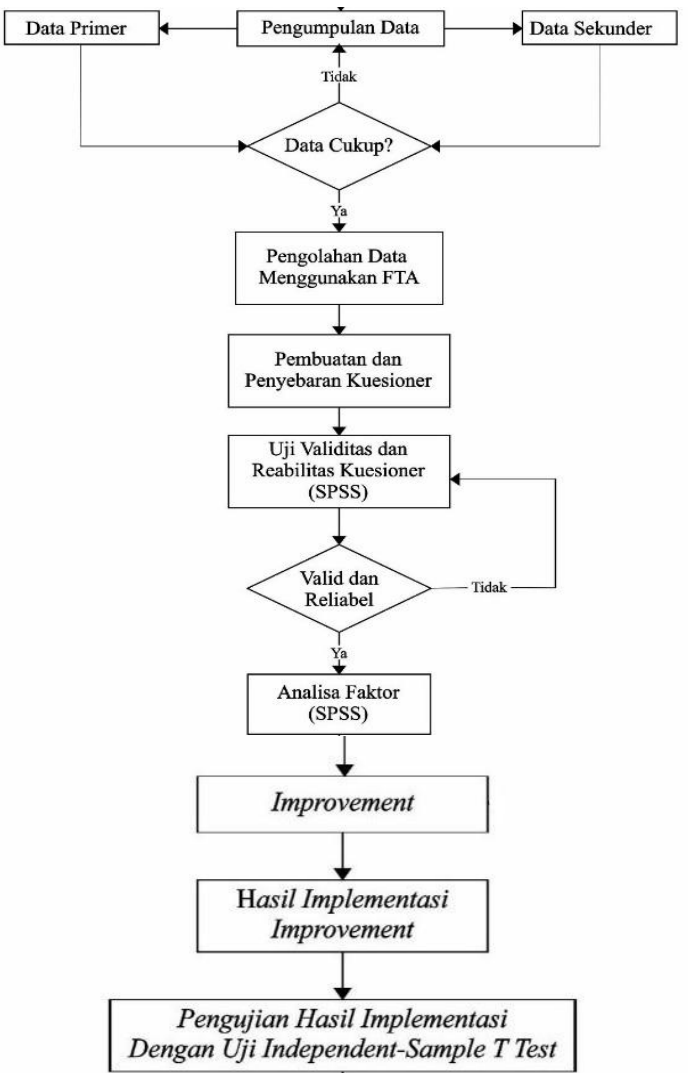

Gambar 1. Flowchart Penelitian

Analisis faktor adalah analisis hubungan antar variabel berdasarkan dimensi dengan pendekatan statistik. Analisis Faktor berusaha mencari common dimension (kesamaan dimensi) yang diambil dari pengembangan hasil metode FTA. Analisis Faktor menggunakan pendekatan confirmatory factor analysis dari faktor yang dibentuk metode FTA (Suliantoro et al., 2017). Analisis hasil faktor yang menjadi prioritas sebagai dasar tindakan improvement dalam usaha meningkatkan kualitas output. Hasil improvement dianalis menggunakan pengujian Analisis Perbandingan Independent-Sample $T$ Test untuk mencari adakah perbedaan secara signifikan setelah perbaikan berdasarkan faktorfaktor yang teridentifikasi (Usman, 2016) 


\section{HASIL DAN PEMBAHASAN}

Varian produk Viro Core Collection (VCC) menggunakan sistem pengadaan make to stock, dimana produk yang diproduksi dimaksudkan untuk mendukung ready stock di Warehouse sesuai dengan rencana produksi. Data volume produksi digunakan untuk menghitung persentase defect berdasarkan total output. Tingkat barang NG pada tahun 2019 hampir mencapai 33\% (Tabel 1).

Tingkat NG yang besar berdampak pada peningkatan biaya produksi dan proses kerja yang berulang untuk memperbaiki produk atau membuat baru sebagai produk pengganti (Bastuti, 2017). Produk NG Viro Core Collection terdiri dari warna belang, textured kasar, motif kasar dan dimensi tidak stabil.

Tabel 1. Tingkat Volume Produksi VCC

\begin{tabular}{cccc}
\hline No & Bulan & Quantity (kg) & $\begin{array}{c}\text { Not Good } \\
\text { (NG) }\end{array}$ \\
\hline 1 & Januari & 9124.12 & 3152.65 \\
2 & Februari & 7759.62 & 2483.36 \\
3 & Maret & 7129.66 & 2698.65 \\
4 & April & 7227.29 & 2560.23 \\
5 & Mei & 4439.68 & 1522.86 \\
6 & Juni & 9888.75 & 2429.94 \\
7 & Juli & 8482.12 & 3363.01 \\
8 & Agustus & 8389.14 & 3189.54 \\
9 & September & 8454.77 & 2172.03 \\
10 & Oktober & 9844.95 & 3214.61 \\
11 & November & 11177.91 & 4183.81 \\
12 & Desember & 15917.04 & 5463.69 \\
Total & & 107835.05 & 36426.11 \\
\hline
\end{tabular}

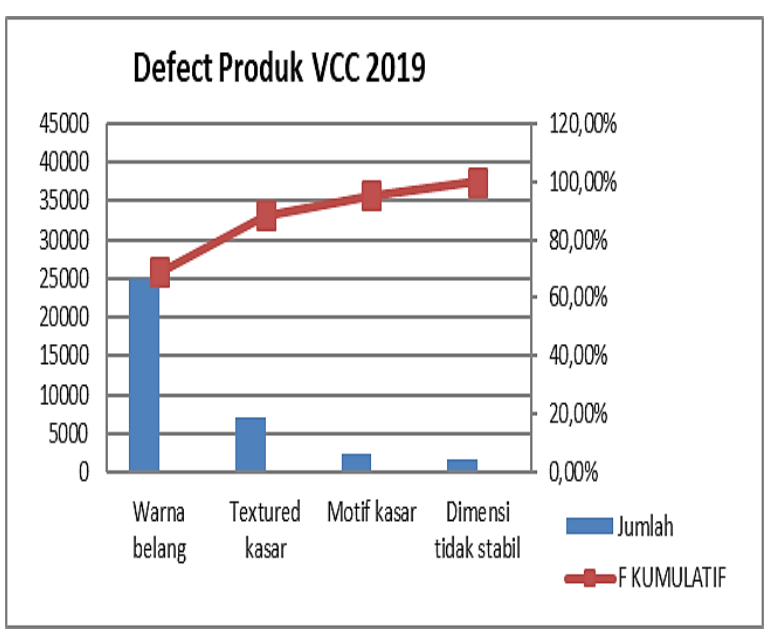

Gambar 2. Diagram Pareto Berdasarkan Jenis Defect pada produk VCC

Berdasarkan diagram pareto diketahui penyebab NG terbesar disebabkan defect karena warna belang (Gambar 2). Penelitian ini fokus pada analisa defect warna belang yang menyebabkan hamper $70 \%$ dari jumlah NG yang terjadi. Contoh defect warna belang, terjadi ketika fiber dianyam maka penampakan pada kursi hasil jadi anyaman terlihat blocking (Gambar 3).
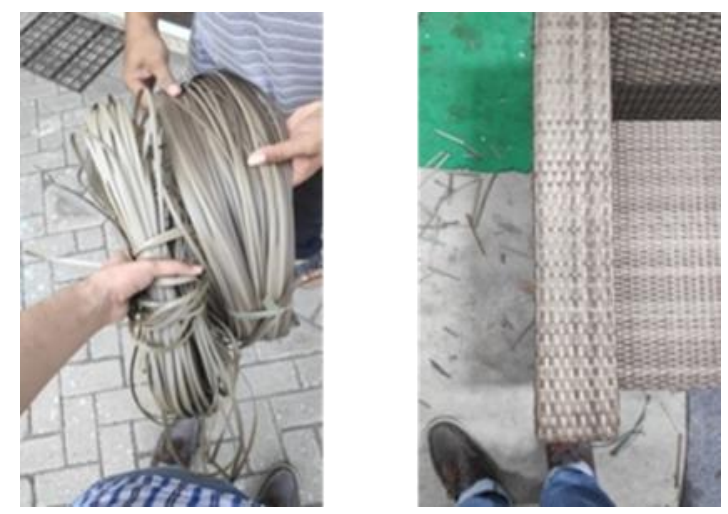

Gambar 3. Defect Warna Belang (Blocking)

\section{Fault Tree Analysis (FTA) dan Analisis Faktor}

Minimum cut-set adalah kumpulan penyebab kegagalan atau kombinasi dari semuanya yang dapat menyebabkan kesalahan proses (Hanif et al., 2015). Minimum cut-set strip berwarna terjadi di mesin ekstrusi yang tidak stabil, suhu mesin tidak stabil dan material berwarna di setiap batch yang berbeda (Gambar $4)$.

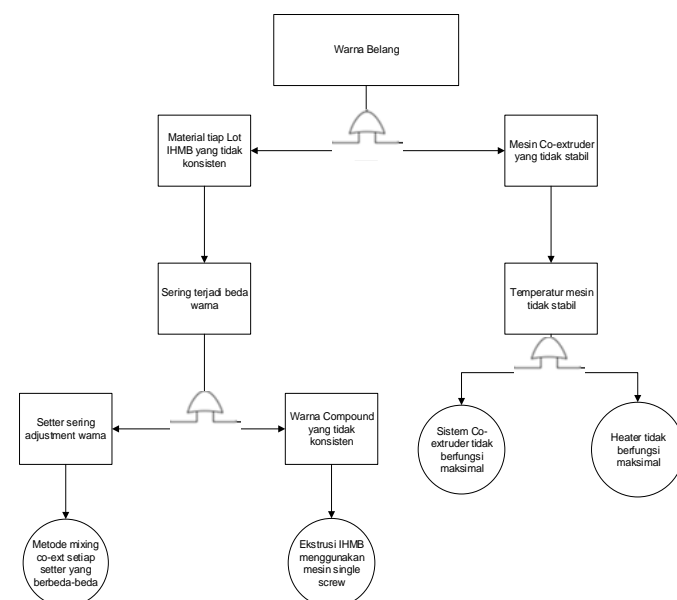

Gambar 4. Fault Tree Analysis untuk Defect Warna Belang

Hasil kuesioner yang diperoleh kemudian dilakukan uji validitas, uji reliabilitas dan uji analisis faktor. Hasil uji validitas menunjukkan secara keseluruhan hasil perhitungan valid (Tabel

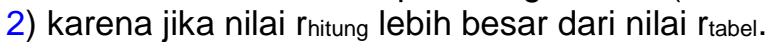
Semua indikator pertanyaan yang digunakan untuk mengukurnya. memiliki koefisien korelasi lebih tinggi dari rabel (Yamin \& Kurniawan, 2009). 
Tabel 2. Correlation Faktor Warna Belang

\begin{tabular}{lccc}
\hline \multicolumn{1}{c}{ Dimensi } & Correlation & $\begin{array}{c}\text { Sign } \\
\text { Value }\end{array}$ & Keterangan \\
\hline $\begin{array}{l}\text { Metode mixing } \\
\text { material Co-extruder } \\
\text { setiap Setter yang } \\
\text { berbeda-beda }\end{array}$ & 0,566 & 0,000 & Valid \\
$\begin{array}{l}\text { Ekstrusi IHMB } \\
\text { menggunakan mesin }\end{array}$ & 0,534 & 0,000 & Valid \\
$\begin{array}{l}\text { Single Screw } \\
\text { Sistem Co-extruder } \\
\text { tidak berfungsi } \\
\text { maksimal }\end{array}$ & 0,304 & 0,001 & Valid \\
$\begin{array}{l}\text { Heater tidak } \\
\text { berfungsi maksimal }\end{array}$ & 0,317 & 0,001 & Valid \\
\hline
\end{tabular}

Tabel 3. Hasil Uji Reliabilitas Faktor Warna Belang

\begin{tabular}{lcc}
\hline \multicolumn{1}{c}{ Dimensi } & $\begin{array}{c}\text { Cronbach's } \\
\text { Alpha }\end{array}$ & Keterangan \\
\hline $\begin{array}{l}\text { Metode mixing material Co- } \\
\text { extruder setiap Setter yang } \\
\text { berbeda-beda }\end{array}$ & 0,962 & Reliable \\
$\begin{array}{l}\text { Ekstrusi IHMB menggunakan } \\
\text { mesin Single Screw }\end{array}$ & 0,962 & Reliable \\
$\begin{array}{l}\text { Sistem Co-extruder tidak } \\
\text { berfungsi maksimal } \\
\text { Heater tidak berfungsi maksimal }\end{array}$ & 0,964 & Reliable \\
\hline
\end{tabular}

Uji reliabilitas dalam penelitian ini menggunakan rumus Alpha Cronbach. Hasil pengujian menunjukkan bahwa semua variabel memiliki koefisien Alpha yang relatif tinggi, yaitu diatas 0,60 (Tabel 3). Hasil uji analisis faktor menunjukkan hasil laporan evaluasi Bartlett 298.055 adalah 0,000 , lebih besar dari $0,05(5 \%)$ dan selalu terjadi antar variabel sehingga memenuhi persyaratan (Tabel 4).

Tabel 4. Hasil Uji Analisa Faktor

\begin{tabular}{lc}
\hline $\begin{array}{l}\text { Determinant of } \\
\text { Correlation Matrix }\end{array}$ & 0,12 \\
Kaiser Meyer Olkin & \\
$\begin{array}{l}\text { Measure of Sampling } \\
(\text { KMO) }\end{array}$ & 0,773 \\
Bartlett's Test of & \\
Sphericity & \\
Signifikansi & 298.055 \\
\hline
\end{tabular}

Koreksi perbaikan diberikan berdasarkan akar penyebab (minimum cut-set) yang diperoleh dari hasil Fault Tree Analysis. Perbaikan dilakukan dengan menganalisa akar penyebab masalah dan memberikan saran untuk perbaikan (Pratama et al., 2016). Saran perbaikan untuk menurunkan defect warna belang difokuskan pada empat permasalahan utama yaitu metode mixing material Co-extruder setiap Setter yang berbeda-beda, ekstrusi IHMB menggunakan mesin Single Screw, sistem Co-extruder tidak berfungsi maksimal, dan heater tidak berfungsi maksimal (Tabel 5).
Tabel 5. Deskripsi Akar Permasalahan dan Usulan Perbaikan Defect Warna Belang

\begin{tabular}{|c|c|c|c|}
\hline No & 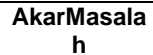 & DeskripsiMasalah & Saran Perbaikan \\
\hline 1 & $\begin{array}{l}\text { Metode } \\
\text { mixing } \\
\text { material Co- } \\
\text { extruder } \\
\text { setiap Setter } \\
\text { yang } \\
\text { berbeda- } \\
\text { beda }\end{array}$ & $\begin{array}{l}\text { Belum ada SOP } \\
\text { mengenai metode } \\
\text { mixing material } \\
\text { pada Co-extruder } \\
\text { sehingga } \\
\text { menyebabkan } \\
\text { kurang } \\
\text { pengetahuan setter } \\
\text { terhadap metode } \\
\text { mixing co-ext yang } \\
\text { berakibat metode } \\
\text { mixing setiap setter } \\
\text { berbeda-beda. }\end{array}$ & $\begin{array}{l}\text { Membuatkan SOP } \\
\text { metode mixing } \\
\text { material pada Co- } \\
\text { extruder sehingga } \\
\text { setiap Setter sama } \\
\text { dalam melakukan } \\
\text { mixing material Co- } \\
\text { extruder. }\end{array}$ \\
\hline 2 & $\begin{array}{l}\text { Ekstrusi } \\
\text { IHMB } \\
\text { menggunak } \\
\text { an mesin } \\
\text { Single } \\
\text { Screw }\end{array}$ & $\begin{array}{l}\text { Ekstrusi material } \\
\text { IHMB } \\
\text { menggunakan } \\
\text { mesin Single } \\
\text { Screw } \\
\text { mengakibatkan } \\
\text { setiap lot IHMB } \\
\text { tidak konsisten. }\end{array}$ & $\begin{array}{l}\text { Ekstrusi material IHMB } \\
\text { sebaiknya dilakukan } \\
\text { menggunakan mesin } \\
\text { Twin Screw sehingga } \\
\text { hasil material IHMB } \\
\text { lebih merata (mixed } \\
\text { well). }\end{array}$ \\
\hline 3 & $\begin{array}{l}\text { Sistem Co- } \\
\text { extruder } \\
\text { tidak } \\
\text { berfungsi } \\
\text { maksimal }\end{array}$ & $\begin{array}{l}\text { Sistem Co-extruder } \\
\text { tidak berfungsi } \\
\text { maksimal } \\
\text { mengakibatkan } \\
\text { strip produk tebal } \\
\text { tipis sehingga } \\
\text { Color tone produk } \\
\text { terlihat belang. }\end{array}$ & $\begin{array}{l}\text { Dilakukan perbaikan } \\
\text { sistem Co-extruder } \\
\text { dan dibuatkan jadwal } \\
\text { preventive } \\
\text { maintenance sehingga } \\
\text { sistem Co-extruder } \\
\text { dapat berfungsi } \\
\text { dengan baik. }\end{array}$ \\
\hline 4 & $\begin{array}{l}\text { Heater tidak } \\
\text { berfungsi } \\
\text { maksimal }\end{array}$ & $\begin{array}{l}\text { Heater tidak } \\
\text { berfungsi maksimal } \\
\text { mengakibatkan } \\
\text { Color tone product } \\
\text { erlihat belang. }\end{array}$ & $\begin{array}{l}\text { Dilakukan perbaikan } \\
\text { heater dan dibuatkan } \\
\text { jadwal preventive } \\
\text { maintenance sehingga } \\
\text { heater dapat berfungsi } \\
\text { dengan baik. }\end{array}$ \\
\hline
\end{tabular}

\section{Analisis Perbandingan Independent Sample T-} Test

Hasil dari implementasi improvement yang diterapkan dilakukan pengujian Analisis Perbandingan Independent-Sample T-Test menggunakan Software SPSS, untuk mengetahui apakah ada perbedaan secara signifikan sebelum dan sesudah perbaikan berdasarkan faktor-faktor yang teridentifikasi (Usman, 2016)

\section{Metode mixing material Co-extruder setiap Setter yang berbeda-beda}

Metode mixing material untuk mesin Coextruder dari setiap Setter yang berbeda-beda karena belum ada SOP mixing material yang berfungsi menjadi panduan kerja, sehingga menyebabkan hasil mixing materialnya berbeda antar Setter. Fenomena tersebut terjadi karena lot produksi untuk satu item produk yang berjalan pada satu lini mesin ekstruder bisa memerlukan durasi beberapa hari, sedangkan dalam satu hari kerja yang terbagi 3 shift terdiri dari 1 Setter untuk tiap shift-nya. Jika hasil kerja mixing dari Settter pada shift berikutnya berbeda dibanding hasil kerja mixing dari Setter pada shift sebelumnya, maka visual warna produk diproses akan berbeda. Jika perbedaan terlalu ekstrim maka Inspector QC akan menolak batch mixed material tersebut dan 
produk jadinya dimasukan dalam kategori waste dan Setter diminta melakukan pencarian warna kembali melalui persiapan batch mixed material baru dan adjustment parameter pada mesin Coextruder.

Kerugian yang terjadi akan sangat banyak yaitu: produk jadi yang yang di-reject tidak bisa dijual dan harus dimusnahkan, waktu tambahan untuk setting parameter mesin Co-extruder untuk pencarian warna sesuai standar, Batch mixed material yang ditolak tidak bisa dipakai, kemungkinan waktu pengiriman kepada customer terlambat, dan lainnya. Jika perbedaan visual warnanya tidak terlalu ekstrim, maka Inspector QC akan meminta Setter untuk melakukan fine adjustment parameter pemanasan Heater dan speed mesin Co-extruder. Kerugian yang terjadi lebih sedikit yaitu: Produk jadi yang di-reject tidak bisa dijual dan harus dimusnahkan, dan waktu tambahan yang diperlukan untuk setting parameter mesin Co-extruder.

Pengujian menggunakan metode Analisis Perbandingan Independent Sample T-Test menggunakan software SPSS atas hipotesis rataan 2 sampel. Berikut ini adalah langkah analisis yang dilakukan:

1) HO: Perbandingan dampak antara metode mixing material untuk mesin Co-extruder setiap Setter sebelum dan sesudah ada SOP adalah sama.

2) H1: Perbandingan dampak antara metode mixing material untuk mesin Co-extruder setiap Setter sebelum dan sesudah ada SOP adalah tidak sama.

3) $\alpha=5 \%$

4) Daerah kritis :

$\mathrm{t}<-\mathrm{t}(\alpha / 2 ; \mathrm{n} 1+\mathrm{n} 2-2)$ atau $\mathrm{t}>\mathrm{t}(\alpha / 2 ; \mathrm{n} 1+\mathrm{n} 2-$ 2)

$\mathrm{t}<-\mathrm{t}(0,025 ; \mathrm{n} 1+\mathrm{n} 2-2)$ tidak ada $\mathrm{t}>\mathrm{t}(0,025 ; \mathrm{n} 1$ $+\mathrm{n} 2-2) \mathrm{t}<-\mathrm{t}(0,025 ; 70)-\mathrm{t}(0,025 ; 70)$ tidak ada $\mathrm{t}>\mathrm{t}(0,025 ; 70)$

$\mathrm{t}<-\mathrm{t} 1.9944$ atau $\mathrm{t}>\mathrm{t} 1.9944$

5) Nilai $t=171.83$

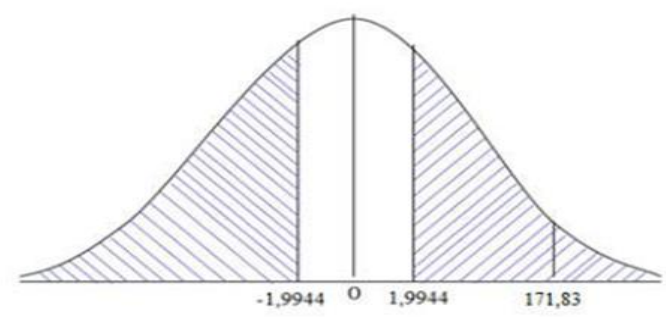

Gambar 5. Kurva T-Test Metode Mixing Material Untuk Mesin Co-extruder Setiap Setter sebelum dan setelah ada SOP

Dari hasil perhitungan dapat ditarik kesimpulan bahwa $\mathrm{HO}$ ditolak karena nilai thitung lebih besar dari tabel $(171,938>1,9944)$, sehingga perbandingan dampak metode mixing material untuk mesin Co-extruder setiap Setter sebelum dan sesudah ada SOP adalah tidak sama. Dari hasil pengujian SPSS ini dapat dilihat bahwa dampak metode mixing material untuk mesin Coextruder setiap Setter sebelum dan sesudah ada SOP adalah berbeda signifikan karena hasil dari Sig.(2-tailed) lebih kecil dari a $(0<0.025)$ sehingga $\mathrm{H} 0$ ditolak (Gambar 5).

\section{Ekstrusi IHMB menggunakan mesin Ekstruder Single Screw}

Ekstrusi material IHMB menggunakan mesin Ekstruder Ulir Tunggal (Single Screw Extruder) menghasilkan undispersed colorant dalam material dasar (base material) dai IHMB, hal ini mengakibatkan hasil dalam satu batch IHMB tidak merata dan konsisten. IHMB sendiri istilah perusahaan untuk pembuatan Masterbatch secara swadaya (Inhouse Masterbatch). Berikut ini adalah langkah analisis yang dilakukan:

1) HO: Perbandingan dampak antara ekstrusi material IHMB menggunakan mesin Ekstruder Ulir Tunggal (Single Screw Extruder) dibanding ekstrusi menggunakan mesin Ekstruder Ulir Ganda (Twin Screw Extruder) adalah sama.

2) H1: Perbandingan dampak antara ekstrusi material IHMB menggunakan mesin Ekstruder Ulir Tunggal (Single Screw Extruder) dibanding ekstrusi menggunakan mesin Ekstruder Ulir Ganda (Twin Screw Extruder) adalah tidak sama.

3) $\alpha=5 \%$

4) Daerah kritis :

$\mathrm{t}<-\mathrm{t}(\alpha / 2 ; \mathrm{n} 1+\mathrm{n} 2-2)$ atau $\mathrm{t}>\mathrm{t}(\alpha / 2 ; \mathrm{n} 1+\mathrm{n} 2-$ 2)

$\mathrm{t}<-\mathrm{t}(0,025 ; \mathrm{n} 1+\mathrm{n} 2-2)$ tidak ada $\mathrm{t}>\mathrm{t}(0,025$; $\mathrm{n} 1+\mathrm{n} 2-2) \mathrm{t}<-\mathrm{t}(0,025 ; 70)-\mathrm{t}(0,025 ; 70)$ tidak ada $\mathrm{t}>\mathrm{t}(0,025 ; 70)$

$\mathrm{t}<-\mathrm{t} 1.9944$ atau $\mathrm{t}>\mathrm{t} 1.9944$

5) Nilai $t=1,02$

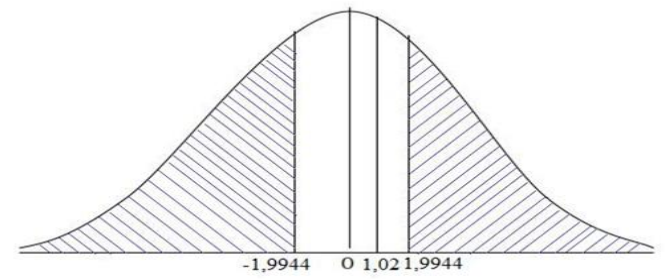

Gambar 6. Kurva T-Test Ekstrusi material IHMB menggunakan mesin Single Screw Extruder dibanding menggunakan mesin Twin Screw Extruder.

Berdasarkan hasil perhitungan dapat ditarik kesimpulan bahwa $\mathrm{HO}$ diterima karena nilai thitung 
lebih kecil dari tabel $(1,012<1,9944)$, sehingga ekstrusi IHMB menggunakan mesin Ekstruder Ulir Tunggal (Single Screw Extruder) sama dengan ekstrusi menggunakan mesin Ekstruder Ulir Ganda (Twin Screw Extruder). Dari hasil pengujian SPSS dapat dilihat bahwa dampak ekstrusi IHMB menggunakan mesin Ekstruder Ulir Tunggal (Single Screw Extruder) sama dengan ekstrusi menggunakan mesin Ekstruder Ulir Ganda (Twin Screw Extruder) sebenarnya tidak berbeda secara signifikan karena hasil dari Sig.(2-tailed) lebih besar dari $\alpha(0,315>0,025)$ sehingga H0 diterima (Gambar 6).

\section{Sistem Co-extruder dan Heater Tidak Berfungsi Maksimal}

Varian produk VCC dibuat dengan konsep rotan sintetis, dimana secara visual warna dan motif didesain mirip rotan alam. Untuk mendapatkan strip aksen warna dan motif seperti kulit rotan alam digunakan tambahan mesin $\mathrm{Co}$ extruder yang disambungkan terhadap mesin Ekstruder utama (Main Extruder). Sistem kerja mesin Main Extruder dan Co-extruder adalah pengaturan kecepatan putar mesin (Line Speed) dari mesin dan pengaturan suhu pemanasan Heater. Jika sistem mesin Co-extruder dan Heater tidak berfungsi maksimal dapat mengakibatkan strip tebal tipis tidak konsisten sehingga color tone produk tidak stabil dan terlihat belang (blocking).

Berikut ini adalah langkah analisis yang dilakukan:

1) HO: Perbandingan dampak antara sistem mesin Co-extruder dan Heater sebelum dan sesudah dilakukan perbaikan dan Preventive Maintenance adalah sama.

2) H1: Perbandingan dampak antara sistem mesin Co-extruder dan Heater sebelum dan sesudah dilakukan perbaikan dan Preventive Maintenance adalah tidak sama.

3) $\alpha=5 \%$

4) Daerah kritis:

$\mathrm{t}<-\mathrm{t}(\alpha / 2 ; \mathrm{n} 1+\mathrm{n} 2-2)$ atau $\mathrm{t}>\mathrm{t}(\mathrm{\alpha} / 2 ; \mathrm{n} 1+\mathrm{n} 2-2)$

$\mathrm{t}<-\mathrm{t}(0.025 ; \mathrm{n} 1+\mathrm{n} 2-2)$ atau $\mathrm{t}>\mathrm{t}(0.025$ $\mathrm{n} 1+\mathrm{n} 2-2)$

$\mathrm{t}<-\mathrm{t}(0.025 ; 70)$ atau $\mathrm{t}>\mathrm{t}(0.025 ; 70)$

$\mathrm{t}<-\mathrm{t} 1,9944$ atau $\mathrm{t}>\mathrm{t1}, 9944$

5) Nilai $t=0.103$

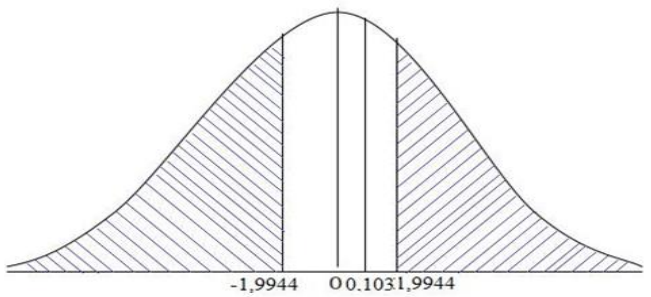

Gambar 7. Kurva T-Test Sistem mesin Coextruder dan Heater sebelum dibanding sesudah dilakukan perbaikan dan Preventive Maintenance
Berdasarkan hasil perhitungan dapat ditarik kesimpulan bahwa $\mathrm{HO}$ diterima karena nilai thitung lebih kecil dari tabel $(0,103<1,9944)$, sehingga sistem mesin Co-extruder dan Heater sebelum dan sesudah dilakukan perbaikan dan Preventive Maintenance adalah sama. Dari hasil pengujian SPSS ini dapat dilihat bahwa dampak sistem mesin Co-extruder dan Heater sebelum dan sesudah dilakukan perbaikan dan Preventive Maintenance sebenarnya tidak berbeda secara signifikan karena hasil dari Sig.(2-tailed) lebih besar dari $\alpha(0,918>0,025)$ sehingga H0 diterima (Gambar 7).

\section{KESIMPULAN}

Dari hasil pengolahan data menggunakan diagram Pareto diketahui defect dominan yang terjadi pada varian produk VCC adalah warna belang (blocking) dengan persentase mencapai $23.24 \%$ dari total produk cacat. Hasil pengujian menggunakan metoda FTA dan Analisis Faktor diketahui bahwa faktor penyebab defect warna belang (blocking) disebabkan: karena Metode mixing material untuk mesin Co-extruder dari setiap Setter yang berbeda-beda, ekstrusi material IHMB menggunakan Single Screw Extruder, Sistem mesin Co-extruder dan Heater tidak berfungsi maksimal, kemudian dilakukan pengujian menggunakan Analisis Perbandingan Independent Sample T-Test menggunakan software SPSS didapat bahwa : Metode mixing material untuk mesin Co-extruder dari setiap Setter yang berbeda-beda sebelum dan sesudah ada SOP adalah berbeda signifikan karena hasil dari Sig.(2-tailed) lebih kecil dari a $(0<0.025)$ sehingga $\mathrm{HO}$ ditolak. Penelitian lanjutan dapat menggunakan lean six sigma untuk lebih mengefisienkan proses dan meminimalkan waste yang terjadi.

\section{UCAPAN TERIMA KASIH}

Terimakasih kepada DIKTI yang telah mendanai penelitian ini pada skema PDP Penelitian Dosen Pemula dan terima kasih pula kepada Universitas Pamulang, khususnya LPPM yang sudah membantu, juga tidak lupa ucapan terima kasih atas dukungan dari Kaprodi dan semua dosen Program Studi Teknik Industri.

\section{DAFTAR PUSTAKA}

Alfatiyah, R., Bastuti, S., \& Kurnia, D. (2020). Implementation of Statistical Quality Control to Reduce Defects in Mabell Nugget Products (Case Study at PT. Petra Sejahtera Abadi). IOP Conference Series: Materials Science and Engineering, 852(1), 012107. https://doi.org/10.1088/1757899X/852/1/012107 
Bastuti, S. (2017). Analisis Kegagalan pada Seksi Marking untuk Menurunkan Klaim Internal dengan Mengaplikasikan Metode Pdca. SINTEK JURNAL: Jurnal IImiah Teknik Mesin, 11(2), 113-122. https://jurnal.umj.ac.id/index.php/sintek/artic le/view/2103

Cahyanti, E. R., Choiri, M., \& Yuniarti, R. (2013). Pengurangan waste pada proses produksi botol $\mathrm{X}$ menggunakan metode lean sigma. Jurnal Rekayasa Dan Manajemen Sistem Industri, 1(1), 37-46. http://jrmsi.studentjournal.ub.ac.id/index.php /jrmsi/article/view/11

Dewi, S. K., \& Sartono, T. D. S. D. (2014). Pendekatan Lean Thinking Untuk Pengurangan Waste Pada Proses Produksi Plastik PE. IENACO Industrial Engineering National Conference, 303-309. http://research-

report.umm.ac.id/index.php/researchreport/article/view/390

Fajarusman, H., Puspitasari, D., \& Bakhtiar, A. (2017). Usulan Perbaikan untuk Mereduksi Defect pada Produk Totem Coat And Hat Stand dengan Pendekatan Lean Manufacturing dan Metode Fault Tree Analysis (Sk: di PT Barali Citramandiri). Industrial Engineering Online Journal, 6(2), $1-15$.

https://ejournal3.undip.ac.id/index.php/ieoj/a rticle/view/16490

Hanif, R. Y., Rukmi, H. S., \& Susanty, S. (2015). Perbaikan kualitas produk keraton luxury di PT. $X$ dengan menggunakan metode failure mode and effect analysis (FMEA) dan FAULT TREE ANALYSIS (FTA). Reka Integra, 3(3), 137-147. https://ejurnal.itenas.ac.id/index.php/rekaint egra/article/view/879

Hazmi, F. W., \& Karningsih, P. D. (2012). Penerapan Lean Manufacturing Untuk Mereduksi waste di PT ARISU. Jurnal Teknik ITS, 1(1), 135-140. http://ejurnal.its.ac.id/index.php/teknik/articl e/view/1777

Herudi, H., Fathurohman, F., \& Supriyadi, S. (2020). Analisa Efektivitas Proses Sinter Plant dengan Pendekatan Lean Manufacturing. Jurnal Intent: Jurnal Industri Dan Teknologi Terpadu, 3(2), 99-110. https://doi.org/10.47080/intent.v3i2.955

Jakfar, A., Setiawan, W. E., \& Masudin, I. (2014). Pengurangan Waste Menggunakan Pendekatan Lean Manufacturing. Jurnal Ilmiah Teknik Industri, 13(1), 43-53. http://journals.ums.ac.id/index.php/jiti/article /view/320

Prakoso, B., Febianti, E., \& Kurniawan, B. (2017). Analisis Proses Produksi Container Accu Menggunakan Metode Lean Manufacturing Pada PT. Presisi Cimanggis Makmur (PCM). Jurnal Teknik Industri Untirta, 5(1), 80-85. https://jurnal.untirta.ac.id/index.php/jti/article /view/1812

Pratama, A., Asih, E. W., \& Wisnubroto, P. (2016). Analisis Penyebab Kecacatan Wreapper pada Mesin Single Flowrap (SFW) Menggunakan Metode Failure Mode Effect and Analysis (FMEA) \& Fault Tree Analysis (FTA) pada PT. Nestle Indonesia. Jurnal Rekavasi, 4(1), 1-9. https://journal.akprind.ac.id/index.php/rekav asi/article/view/335

Pusporini, P., \& Andesta, D. (2012). Integrasi Model Lean Sigma Untuk Peningkatan Kualitas Produk. Jurnal Teknik Industri, 10(2), 91-97. https://ejournal.umm.ac.id/index.php/industri /article/view/589

Suliantoro, H., Susanto, N., Prastawa, H., Sihombing, I., \& Mustikasari, A. (2017). Penerapan metode overall equipment effectiveness (OEE) dan fault tree analysis (FTA) untuk mengukur efektifitas mesin reng. J@ti Undip: Jurnal Teknik Industri, 12(2), 105. https://doi.org/10.14710/jati.12.2.105-118

Usman, M. (2016). On consistency and limitation of independent t-test Kolmogorov Smirnov Test and Mann Whitney U test. IOSR Journal of Mathematics, 12(4), 22-27. https://www.iosrjournals.org/iosrjm/papers/Vol12-issue4/Version5/E1204052227.pdf

Yamin, S., \& Kurniawan, H. (2009). SPSS Complete: Teknik Analisis Statistik Terlengkap dengan Software SPSS. Jakarta: Salemba Infotek. https://onesearch.id/Record/IOS7006.slims11430 